\title{
Influence of Bleaching Technologies on the Aerobic Biodegradability of Effluents from Eucalyptus Kraft Pulps Factories
}

\author{
Gladys Vidal $^{1 *}$, Manuel Soto ${ }^{2}$, Ramón Méndez ${ }^{3}$ and Juan Manuel Lema ${ }^{3}$ \\ ${ }^{1}$ Department of Chemical Engineering, University of La Frontera. P.O. Box 54-D, Temuco-Chile. ${ }^{2}$ Department of \\ Industrial and Fundamental Chemistry, University of A Coruña. A Zapateira s/n, E-15071 - A Coruña, Spain; \\ ${ }^{3}$ Department of Chemical Engineering, University of Santiago de Compostela. Avenida das Ciencias s/n E-15706 - \\ Santiago de Compostela, Spain.
}

\begin{abstract}
Aerobic biodegradability of effluents from different Eucalyptus kraft pulp bleaching processes was studied. Bleaching effluents were obtained from: i) Chlorine Bleaching $(C B)$ processes, with partial substitution of chlorine by chlorine dioxide and ii) Total Chlorine Free (TCF) processes. The overall biodegradability, in terms of Chemical Oxygen Demand (COD) was higher for TCF effluents (96-98\%) than for CB ones (82-93\%). Taking into account the higher organic load of CB effluents, this fact implied a much higher residual COD for them (100-180 mg/L) than for TCF effluents (10-30 mg/L). Furthermore, a refractory fraction of molecular weight higher than 43,000 Da was found in $C B$ effluent, which implied the necessity of a further specific treatment. The toxicity was completely removed after the biological treatment.
\end{abstract}

Key words: Kraft pulp bleaching wastewater, Aerobic biodegradation, Pulp bleaching technology, TCF, CB.

\section{INTRODUCTION}

Forest industry effluents are responsible for large amounts of Biological Oxygen Demand (BOD), Chemical Oxygen Demand (COD), Suspended Solids (SS), color and toxicity discharges into natural waters. BOD results from the easily biodegradable components such as carbohydrates, organic acids and alcohols.

Bleaching effluents from the production of kraft pulps are important sources of both BOD and toxic compounds. Toxicity in chlorine bleaching effluents is related to the presence of organochlorine compounds (AOX) and wood resin compounds (Sierra et al., 1994; Puhakka et al., 1994). Toxicity may affect both the natural ecosystem (ecotoxicity) (Eysembach et al., 1990; Crooks and Sikes, 1990) and microorganisms involved in biological treatments.

Reduction of COD, BOD and AOX have received much attention in recent years. New technologies as extended cooking and/or oxygen delignification (Kinstrey, 1993) were developed in order to lower the consumption of bleaching reagents. Besides, elemental chlorine was partially or totally substituted by chlorine dioxide to produce Elemental Chlorine Free (ECF) pulps (Wong et al., 1978; McFarlane et al., 1971). More recently the use of non-chlorine bleaching reagents such as hydrogen peroxide and ozone etc. (Abbot and Sun, 1993; Cates et al., 1995) allowed to produce Totally Chlorine Free (TCF) pulps.

In spite of the pollution reductions achieved by these modified processes, external treatment of bleached kraft mill effluents is now required to meet legal discharge criteria. Activated sludge process or aerated lagoons are the main systems used for the treatment of kraft mill wastewaters (Strehler and Welander, 1994). Aerobic treatments allow for the removal of most of the biodegradable charge, reaching BOD reductions of 70-98\% (Boman et al., 1991; Saunamäki et al., 1991). However, COD and AOX removals

\footnotetext{
* Author for correspondence
} 
are lower, ranging from 17 to $69 \%$ for COD (Boman et al., 1991; Çeçen et al., 1992) and from 10 to $65 \%$ for AOX (Haberl et al., 1991; Stuthridge and McFarlane, 1994).

The biological removal of AOX in aerated systems seems to be more difficult for hardwood pulp bleaching effluents (Bryant and Amy, 1991), no removals being reported for Eucalyptus pulp bleaching effluents (Boyden et al., 1994). Furthermore, the molecular weight of AOX compounds influences biodegradation as the biodegradability is higher for low molecular weight fractions (Bryant et al., 1987). Aerobic treatment allows the removal of wood extractives to a high extent, while chlorinated phenolic compounds are only partially removed (Eysembach et al., 1990). Besides, internal process modifications would interact with the characteristics and treatability of the effluents and, therefore, the efficiency of biological treatment may be affected.

The goal of this paper is to study the influence of bleaching technologies on the aerobic biodegradability of effluents from Eucalyptus kraft mills. The bleaching sequences assessed include both $\mathrm{CB}$ processes with partial substitution of chlorine by chlorine dioxide and TCF processes.

\section{MATERIALS AND METHODS}

Analytical methods. COD was measured as described in Standard Methods (APHA, 1985). Total and soluble $\mathrm{COD}\left(\mathrm{COD}_{\mathrm{t}}, \mathrm{COD}_{\mathrm{s}}\right)$ were obtained on the whole and fiber glass filtered samples, respectively. Total Carbon (TC) and Total Organic Carbon (TOC) were determined using a TOC-5000 Shimadzu equipment with infrared detector. The acute toxicity was determined by luminescence with Photobacterium phosphoreum (Arbucke and Alleman, 1992), using a Microtox apparatus. The results are reported as $\mathrm{EC}_{50}(\% \mathrm{v} / \mathrm{v})$, that is, the effluent concentration that reduces $50 \%$ of the light emission.
Molecular weight distribution was analyzed by Fast Performance Liquid Chromatography (FPLC), equipped with a Superdex 75 HR 10/30 column (Pharmacia, Piscataway, USA) and a ultraviolet absorbance LCC 501 Plus analyzer. The ultraviolet absorbance at $280 \mathrm{~nm}, \mathrm{UV}_{280}$, was considered indicative of the lignin content of wastewaters. A $750 \mathrm{mM}$ buffer solution containing $10 \%(\mathrm{v} / \mathrm{v})$ of methanol was used as eluent. The biochemicals used for molecular weight markers included Aprotinin ( $\mathrm{MW}=$ 6,500), Ribonuclease $(\mathrm{MW}=13,700)$ and Ovalbumin (MW = 43,000).

Wastewaters. The wastewaters used in this study came from two different mills that apply the kraft process to pulp Eucalyptus wood. Two types of wastewater were considered: the first was derived from a $\mathrm{C} / \mathrm{D}(\mathrm{EO}) \mathrm{C} / \mathrm{D}$ bleaching sequence, whereas the second was produced in a TCF process, using peroxide as bleaching agent $(\mathrm{PQP})$. All samples were collected at steady state conditions.

Biomass. Two sludges were used in the preliminary selection assays. The first one (S1) came from an aerated pond, treating only the bleaching effluent (aerobic sludge), while the second (S2) came from an aerated pond, treating the overall effluent from kraft pulp mill (facultative sludge).

Biological assays. The aerobic biodegradability batch assays were carried out at $20{ }^{\circ} \mathrm{C}$ in 500 $\mathrm{mL}$ open bottles (with $300 \mathrm{~mL}$ of working volume) in a shaker at $80 \mathrm{rpm}$. Each assay was carried out in duplicate, and the average values are reported. The assay medium was prepared by adding macronutrients to the wastewater until a final ratio $\mathrm{C}: \mathrm{N}: \mathrm{P}: \mathrm{KCl}$ of 100:20:5:2 was reached. The $\mathrm{pH}$ was adjusted to $7.0 \pm 0.1$ with concentrated $\mathrm{NaOH}$ or $\mathrm{HCl}$. The medium was then inoculated with either sludge, resulting a sludge concentration of $3 \mathrm{gVSS} / \mathrm{L}$ in all experiments. TOC was monitored daily in all of the assays, while only initial and final values for $\mathrm{pH}, \mathrm{COD}$, acute toxicity and MW distribution were determined. 


\section{RESULTS AND DISCUSSION}

Wastewater characteristics. Table 1 presents the main characteristics of the wastewaters used in this work.

Table 1: Characteristics of wastewater from kraft pulp bleaching.

\begin{tabular}{lcc}
\hline \multicolumn{3}{c}{ Effluent } \\
\hline $\begin{array}{l}\text { Bleaching } \\
\text { sequence }\end{array}$ & $\mathrm{C} / \mathrm{D}(\mathrm{EO}) \mathrm{C} / \mathrm{D}$ & $\mathrm{PQP}$ \\
$\mathrm{COD}_{\mathrm{t}}(\mathrm{mg} / \mathrm{L})$ & $800-1,350$ & $670-730$ \\
$\mathrm{COD}_{\mathrm{s}}(\mathrm{mg} / \mathrm{L})$ & $730-1,360$ & $550-650$ \\
$\mathrm{TC}(\mathrm{mg} / \mathrm{L})$ & $452-776$ & $306-407$ \\
$\mathrm{TOC}(\mathrm{mg} / \mathrm{L})$ & $448-735$ & $294-401$ \\
$\mathrm{pH}$ & $3.5-7.0$ & $7.1-10.4$ \\
$\mathrm{EC}_{50}(\% \mathrm{vol})$. & $4.4-7.4$ & $10.6-27.5$ \\
\hline
\end{tabular}

The type of industrial process used to bleach Eucalyptus kraft pulps has a strong influence on the characteristics of the effluents. The $\mathrm{pH}$ of effluents from bleaching sequences containing chlorination step is acidic, while the $\mathrm{pH}$ is neutral or alkaline for those utilizing peroxide. In all cases the content of suspended solid is very low. COD, TOC and TC values are considerably higher for $\mathrm{CB}$ effluents than those for TCF effluents. Furthermore, acute toxicity, measured by the Microtox method, is higher for effluents from chlorine bleaching.

Sludge selection. Figure 1 shows the results of preliminary biodegradability assays carried out to select the best sludge. S1 and S2 sludges were tested on both $\mathrm{C} / \mathrm{D}(\mathrm{EO}) \mathrm{C} / \mathrm{D}$ and PQP effluents.

In general, the aerobic sludge S1 allowed for higher COD and TOC removals, hence, it was selected for the next experiments. Therefore, sludge adaptation was shown to be an important step towards bioremedation, particularly for chlorine bleaching effluents such as the $\mathrm{C} / \mathrm{D}(\mathrm{EO}) \mathrm{C} / \mathrm{D}$ effluent.

The acclimatization of the aerobic sludge to the bleaching wastewater seems to be a key factor affecting the efficiency of organic matter removal. Therefore, it is recommendable to design a start-up of the biological system including a strategy to acclimate the sludge before treating bleaching effluents.

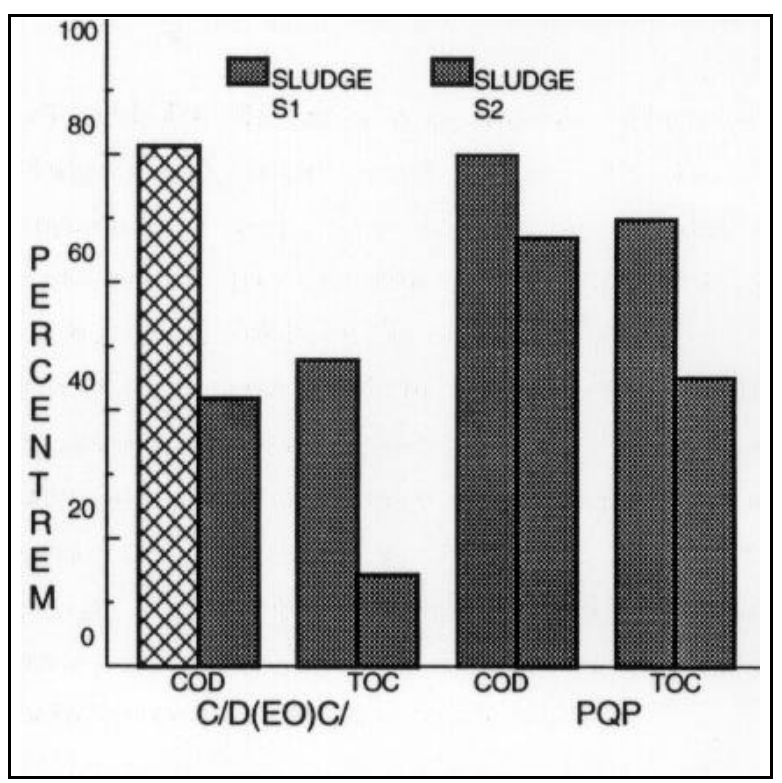

Figure 1: $\mathrm{COD}$ and TOC removals reached during the preliminary sludge selection assays.

Biological treatment and detoxification of bleaching effluents. The results of biodegradability assays for $\mathrm{C} / \mathrm{D}(\mathrm{EO}) \mathrm{C} / \mathrm{D}$ and PQP bleaching effluents are shown in Table 2. The efficiency of COD removal was higher for TCF effluents, probably due to the higher content of refractory compounds in the $\mathrm{CB}$ effluents. This point will be analyzed and discussed later.

Biological treatment and detoxification of bleaching effluents. The results of biodegradability assays for $\mathrm{C} / \mathrm{D}(\mathrm{EO}) \mathrm{C} / \mathrm{D}$ and PQP bleaching effluents are shown in Table 2. The efficiency of COD removal was higher for TCF effluents, probably due to the higher content of refractory compounds in the $\mathrm{CB}$ effluents. This point will be analyzed and discussed later.

However, in spite of the different TOC concentration of the two effluents, TOC removal rates were very similar: $8.2(\mathrm{C} / \mathrm{D}(\mathrm{EO}) \mathrm{C} / \mathrm{D})$ and 7.1 (PQP) mg TOC/L.h (Figure 4, curve C1). The overall TOC removal $\left(\right.$ TOC $_{\mathrm{r}}$ ) after a treatment period of 13 days was in the range of $80-91 \%$, while the overall COD removal $\left(\mathrm{COD}_{\mathrm{r}}\right)$ ranged from 82 to $98 \%$ for both effluents. 
Table 2: Biodegradability of wastewater from bleaching process.

\begin{tabular}{lcccc}
\hline Bleaching Process & $\mathrm{COD}_{\mathrm{r}}(\%)$ & $\mathrm{TOC}_{\mathrm{r}}(\%)$ & $\mathrm{EC}_{50}(\%$ vol. $)$ & Final COD $(\mathrm{mg} / \mathrm{L})$ \\
\hline $\mathrm{C} / \mathrm{D}(\mathrm{EO}) \mathrm{C} / \mathrm{D}$ & $82-93$ & $80-91$ & $>100$ & $100-180$ \\
$\mathrm{PQP}$ & $96-98$ & $85-90$ & $>100$ & $10-30$
\end{tabular}

The final COD values for the treated effluents was much higher in the CB wastewater (100-180 $\mathrm{mg} / \mathrm{L})$ compared to that from the TCF process $(10-30 \mathrm{mg} / \mathrm{L})$. This was probably a function of the initial organic load of both effluents. The ecotoxicity, measured by the Microtox method, was completely removed in all of the assays, yielding final effluents with $\mathrm{EC}_{50}$ higher than $100 \%$.

In a previous study (Vidal et al., 1997), we have found that the anaerobic biodegradability of TCF effluents was $10 \%$ higher than that of the corresponding CB effluents. This showed that, compared to the anaerobic treatment, aerobic processes were less influenced by the presence of different compounds produced by each of the bleaching technologies. Besides, a residual toxicity still remained after the anaerobic biodegradation.

Biodegradability of high molecular weight compounds. In Figures 2 and 3, the molecular weight (MW) distributions of $\mathrm{C} / \mathrm{D}(\mathrm{EO}) \mathrm{C} / \mathrm{D}$ and PQP effluents are shown before and after the biological treatment. The MW compounds were higher for the $\mathrm{C} / \mathrm{D}(\mathrm{EO}) \mathrm{C} / \mathrm{D}$ effluent, compared to the PQP effluent. For the $\mathrm{C} / \mathrm{D}(\mathrm{EO}) \mathrm{C} / \mathrm{D}$ bleaching effluent, the main fraction had a MW over 40,000 Da, although minor fractions with lower MW were also detected. In contrast, the main fraction of the PQP bleaching effluent had a MW of about 4,000 Da.

These results agreed with those obtained by Cates et al. (1995) and Dahlman et al. (1995), taking into account that hydrogen peroxide was responsible for a faster oxidation of the lignin constituents, compared to chlorine or chlorine dioxide (Folke et al., 1993).

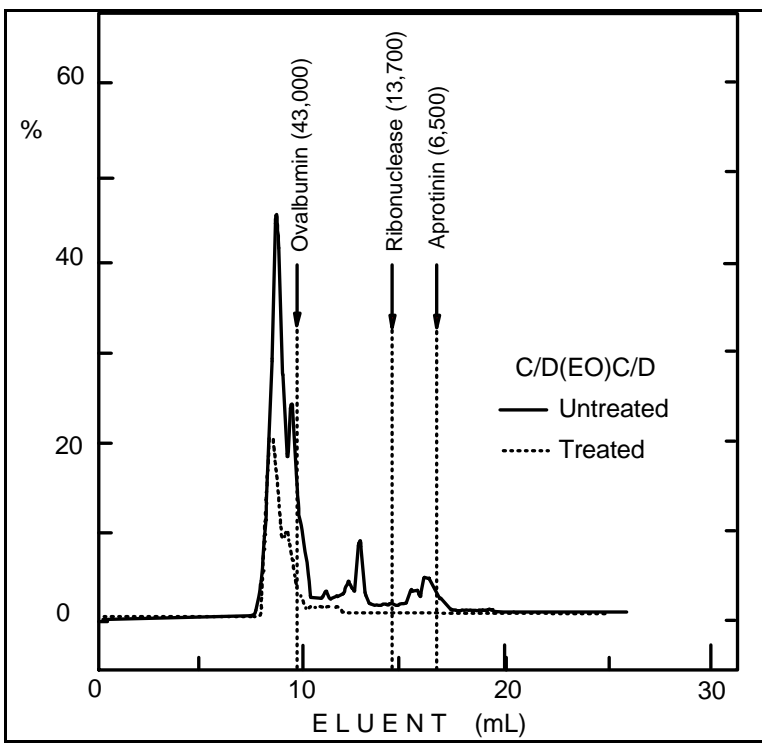

Figure 2: $\mathrm{MW}$ distribution of ultraviolet absorbing $(280 \mathrm{~nm})$ organic constituents for C/D(EO)C/D bleaching effluent before and after aerobic treatment.

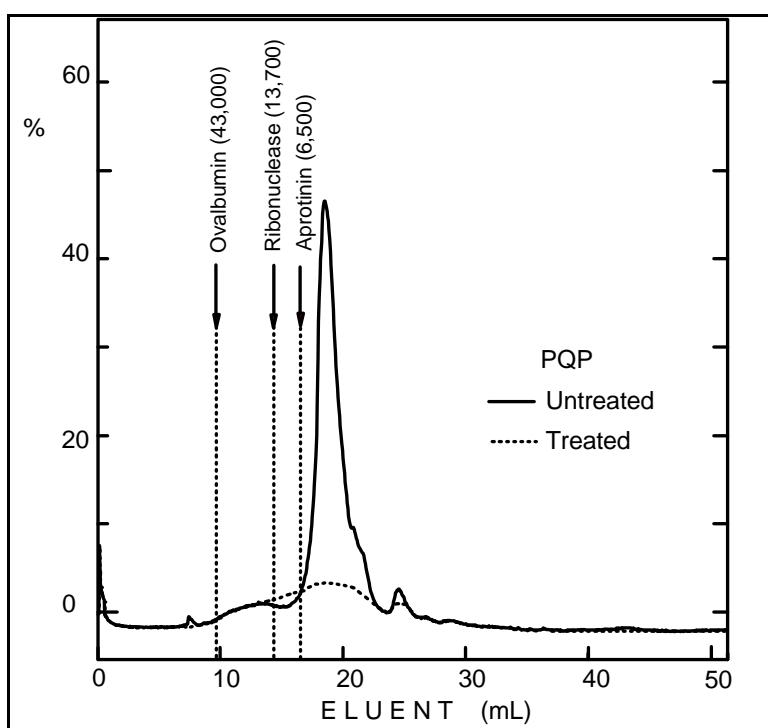

Figure 3: $\mathrm{MW}$ distribution of ultraviolet absorbing $(280 \mathrm{~nm})$ organic constituents for PQP bleaching effluent before and after aerobic treatment.

In both the cases, the aerobic treatment removed an important fraction of the high MW compounds, as shown by the differences in the MW distribution obtained before and after the biodegradation assays. MW fractions lower than 
40,000 Da were completely removed from $\mathrm{C} / \mathrm{D}(\mathrm{EO}) \mathrm{C} / \mathrm{D}$ bleaching effluent, although a refractory fraction with a MW higher than 43,000 Da was still detected.

Dahlman et al. (1995) have also found that the aerobic biodegradation of high MW compounds is more difficult than that of low MW fractions. Fractions of lower MW are also degraded by anaerobic bacteria (Sierra-Alvarez, 1990).

The effect of wastewater concentration on the aerobic biodegradability. Different samples of $\mathrm{C} / \mathrm{D}(\mathrm{EO}) \mathrm{C} / \mathrm{D}$ and $\mathrm{PQP}$ effluents were concentrated by evaporation and used for biodegradability assays to study the effect of wastewater concentration. From an original TOC of $744 \mathrm{mg} / \mathrm{L}(\mathrm{C} 1)$, the $\mathrm{C} / \mathrm{D}(\mathrm{EO}) \mathrm{C} / \mathrm{D}$ effluent was concentrated up to 1100 (C2) and 1370 (C3) $\mathrm{mg} / \mathrm{L}$, whereas, the PQP effluent, with an original TOC concentration of $401 \mathrm{mg} / \mathrm{L}$ (C1), was concentrated to 632 (C2) and 901 (C3) $\mathrm{mg} / \mathrm{L}$. Therefore, the highest assayed concentrations were about twice the original one. The TOC removal for these assays is shown in Figure 4.

The percentages of TOC removals were similar, suggesting that the initial TOC concentration of the wastewater was not a key factor for biodegradation.

The TOC removal rates, associated with different wastewater concentrations, were obtained from Figure 4 and plotted in Figure 5 against TOC concentration. For the $\mathrm{C} / \mathrm{D}(\mathrm{EO}) \mathrm{C} / \mathrm{D}$ effluent, the rate increased almost linearly with respect to TOC concentration, while a practically constant value was obtained for the PQP effluent. These experiments clearly showed that no inhibition problems were likely to appear when were higher wastewater concentration are produced in the mill.

However, the concentration of refractory compounds in the treated effluents became higher as the wastewater load increased. This would imply the necessity for a complementary treatment system when higher loaded wastewaters are expected to be produced in the mill.

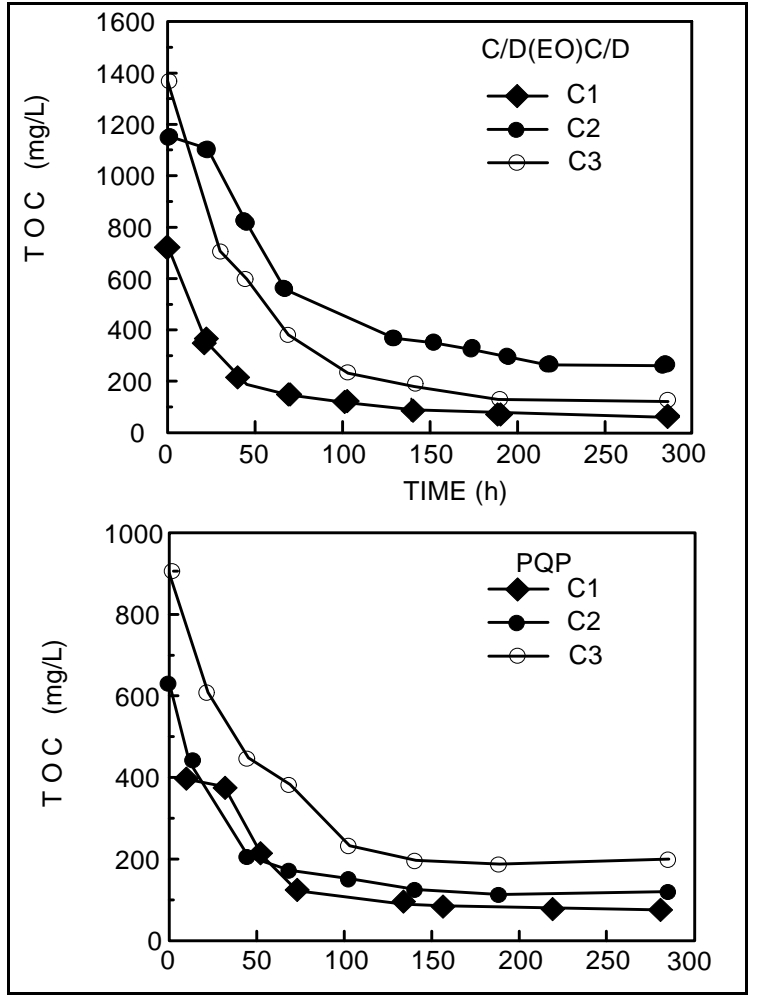

Figure 4: Kinetics of TOC removal in aerobic batch assays for $\mathrm{C} / \mathrm{D}(\mathrm{EO}) \mathrm{C} / \mathrm{D}$ and $\mathrm{PQP}$ bleaching effluents at different TOC levels.

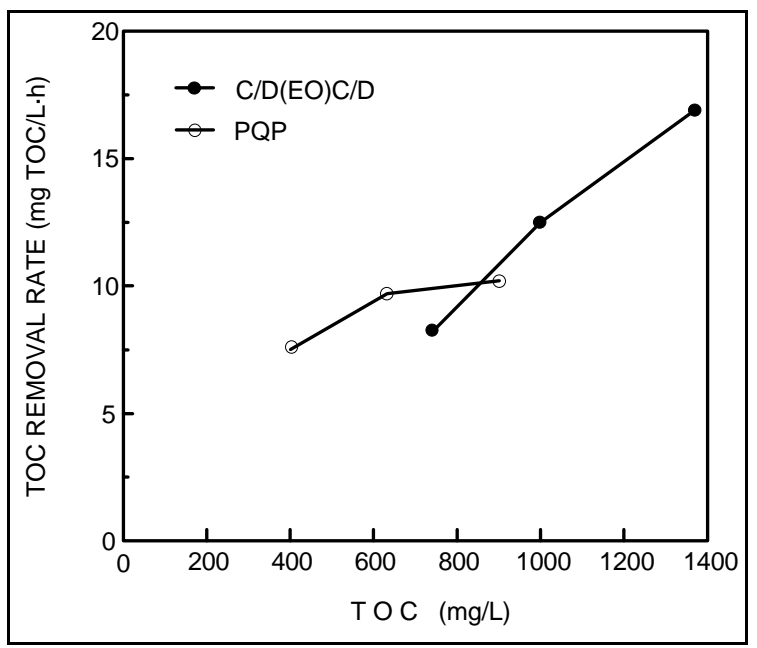

Figure 5: TOC removal rate as a function of TOC concentration for $\mathrm{C} / \mathrm{D}(\mathrm{EO}) \mathrm{C} / \mathrm{D}$ and $\mathrm{PQP}$ bleaching effluents.

\section{CONCLUSIONS}

The industrial bleaching process of Eucalyptus kraft pulps has a strong influence on the characteristics of the effluents. Bleaching sequences containing chlorine steps produce effluents with lower $\mathrm{pH}$ and higher COD, TOC 
and TC values than those utilizing peroxide. Besides, ecotoxicity, measured by the Microtox method, is higher for effluents containing chlorine.

The overall TOC removal by aerobic bacteria was in the range $80-91 \%$ for both types of effluents, while the overall COD removal ranged from $82-93 \%$ and $96-98 \%$ for $\mathrm{CB}$ and TCF wastewater, respectively.

The ecotoxicity was observed to be completely removed in all cases, obtaining final effluents with a $\mathrm{EC}_{50}$ higher than $100 \%$ in volume.

The aerobic treatment allowed for the almost complete removal of the main fraction of lignin related compounds, although a refractory fraction of MW higher than 43,000 Da was found in the $\mathrm{C} / \mathrm{D}(\mathrm{EO}) \mathrm{C} / \mathrm{D}$ bleaching effluent.

Higher organic concentration of the effluents up to twice the original organic concentration (from 744 to $1370 \mathrm{mg}$ TOC/L for the C/D(EO)C/D effluent, and from 401 to $901 \mathrm{mg}$ TOC/L for PQP effluent) did not affect the biodegradation rate, although the concentration of refractory compounds in the remaining effluents increased.

\section{ACKNOWLEDGMENTS}

This work was partially supported by FONDECYT 1970868 and Agencia de Cooperación Iberoamericana Project ICIUSC/UFRO-97.

\section{RESUMO}

A biodegradabilidade aerobica das águas residuais provenientes de diferentes procesos de branqueos de pulpa kraft foi estudada. Os efluentes $\mathrm{S} \pm \mathrm{O}$ gerados no branqueo com cloro ou parcialmente sustituido com dioxido de cloro (CB) ou bem em processos livres do cloro (TCF). A biodegradabilidade, quantificada como DQO foi maior para as águas do processo CB. Tendo em conta o elevado conteúdo orgânico do efluente $\mathrm{CB}$ obteinse uma maior concentraç \pm 0 do DQO final neste efluente comparado com o efluente TCF. Uma fracçao recalcitrante maior a
43,000 Da no effluente BC foi encontrada, isto significa um tratamento adicional específico para sua eliminaç \pm 0 . A toxicidade foi totalmente eliminada despois do tratamento aeraç \pm o.

\section{REFERENCES}

APHA-AWWA-WPCF. (1985), Standard Methods for Examination of Water and Wastewater. 16th Ed. Washington.

Abbot, J. and Sun, Y.P. (1993), Delignification and brightening of eucalyptus Kraft pulp with hydrogen peroxide and UV radiation. Appita, 46 (3), 198-202.

Arbuckle, W. and Alleman, J. (1992), Effluent toxicity testing using nitrifiers and Microtox. Water Environ. Res., 64 (3), 263-267.

Boman, B., Ek, M., Heyman, W. and Frostell, B. (1991), Membrane filtration combined with biological treatment for purification of bleach plant effluents. Wat. Sci. Tech., 24 (3/4), 219228.

Boyden, B.H., Li, X.Z., Schulz, T.J., Hijazin, O., Peiris, P. and Bavor, J. (1994), Treatment of bleachery effluents from Kraft mill pulping mature eucalyptus. Wat. Sci. Tech., 29 (5/6), 247-258.

Bryant, C.W. and Amy, G.L. (1991), Biological dehalogenation of Kraft mill wastewaters. Wat. Sci. Tech., 21 (4/5), 231-239.

Bryant, C., Amy, G. and Alleman, B. (1987), Organic halide and organic distribution and removal in pulp and paper wastewater lagoon. Journal WPCF 59 (10), 890-896.

Cates, D., Eggert, C., Yang, J. and Eriksson, K. (1995), Comparison of effluents from TCF and ECF bleaching of Kraft pulps. Tappi Journal, 78(12), 93-98.

Çeçen, F., Urban, W. and Haberl, R. (1992), Biological and advanced treatment of sulfate pulp bleaching effluents. Wat. Sci. Tech., 26 $(1 / 2), 435-444$.

Crooks, R. and Sikes, J. (1990), Environmental effects of bleaching Kraft mill effluents. Appita, 43(1), 67-76.

Dahlman, O., Reimann, A., Stromberg, L. and Mörck, R. (1995), High molecular weight effluent materials from modern ECF and TCF bleaching. Tappi Journal, 78(12), 99109. 
Eysenbach, E., Neal, L. and Owens, J. (1990), Pulping effluents in the aquatic environment. Tappi Journal, 73(4), 78-84.

Folke, J., Duoplan, E., Lehtinen, J. and McCubbin, N. (1993), Chlorine dioxide in pulp bleaching. Technical aspects and environmental effects. European Environmental Research Group, Helsinki, Finland.

Haberl, R., Urban, W., Gehringer, P. and Szinovatz, W. (1991), Treatment of pulp bleaching effluents by activated sludge, precipitation, ozonation and irradiation. Wat. Sci. Tech., 24 (3/4), 229-239

Kinstrey, R.B. (1993), An overview of strategies for reducing the environmental impact of bleach-plant effluents. Tappi Journal, 76(3), 105-113.

McFarlane, P., Allison, R., Clark, A., Mackie, K. (1971), The effects of chlorination conditions on the AOX and chlorinated phenol content of Kraft bleach plant wastewater. Wat. Sci. Tech., 24(3/4), 55-63.

Puhakka, J.A., Makinen, P.M., Lundin, M. and Ferguson, J.F. (1994), Aerobic and anaerobic biotransformation and treatment of chlorinated pulp bleach waste constituents. Wat. Sci. Tech., 29 (5/6),73-

Sierra-Alvarez, R., Harbrecht, J., Kortekaas, S. and Lettinga, G. (1990), The continuous anaerobic treatment of pulping wastewater. $J$. Ferment. Bioengineer., 70(2), 119-127.
Sierra, R., Field, J.A., Kortekaas, S. and Lettinga, G. (1994), Overview of the anaerobic toxicity caused by organic forest industry wastewater pollutants. Wat. Sci Tech., 29(5/6), 353-364.

Strehler, A. and Welander, T. (1994), A novel method for biological treatment of bleached Kraft mill wastewater. Wat. Sci. Tech., 29 (5/6), 295-301.

Stuthridge, T. and McFarlane, P. (1994), Absorbable organic halide removal mechanisms in a pulp and paper mill aerated lagoon treatment system. Water Sci. Tech., 29 (5/6), 195-208.

Saunamäki, R., Jokinen, K., Järvinen, R. and Savolainen, M. (1991), Factors affecting the removal and discharge of organic chlorine compounds at activate sludge treatment plants. Wat. Sci. Tech., 24 (3/4), 295-307.

Vidal, G., Soto, M., Méndez-Pampín, R., Field, J. and Lema, J.M. (1997), Anaerobic biodegradability and toxicity of wastewaters from chlorine and total chlorine free bleaching of eucalyptus Kraft pulps. Wat. Res., 31(10), 2487-2494.

Wong, M., Wostradowki, R., Prahacs, S. (1978), Toxicity, BOD and color of effluents from novel bleaching processes. Pulp and Paper Canada, 79(7), 41-47 (1978). 